\title{
Antiquity Matters
}


This page intentionally left blank 


\section{Antiquity Matters}

FREDERIC RAPHAEL

Yale UNIVERSITY PRESS

New Haven and London 
Published with assistance from the foundation established in memory of Amasa Stone Mather of the Class of 1907, Yale College.

Copyright $\odot 2017$ by Frederic Raphael.

All rights reserved.

This book may not be reproduced, in whole or in part, including illustrations, in any form (beyond that copying permitted by Sections 107 and 108 of the U.S. Copyright Law and except by reviewers for the public press), without written permission from the publishers.

Yale University Press books may be purchased in quantity for educational, business, or promotional use. For information, please e-mail sales.press@yale.edu (U.S. office) or sales@yaleup.co.uk (U.K. office).

Set in Minion type by IDS Infotech Ltd.

Printed in the United States of America.

Library of Congress Control Number: 2017933336

ISBN 978-0-300-21537-3 (hardcover : alk. paper)

A catalogue record for this book is available from the British Library.

This paper meets the requirements of ANSI/NISO Z39.48-1992 (Permanence of Paper). 
For the wise man, Greece is everywhere.

- Philostratus (3rd century C.E.)

You never step into the same past twice.

-FEDERICO GARCIA LORCA (20th century C.E.)

Oh those Greeks! They knew how to live: what is needed for that is to stop bravely at the surface, the fold, the skin: to worship appearance, to believe in shapes, tones, words-in the whole Olympus of appearance!

—FRIEDRICH NIETZSCHE (19th century C.E.)

Skammenous dromous xanaskavo.

(Ways already excavated, I dig up again.)

— GEORge SEFERIS (20th century C.E.) 
This page intentionally left blank 